\title{
鼻腔に発生した血管平滑筋腫の一症例
}

\author{
竹内 和即 - 大槻 好正 - 相川 通 \\ 小猃 㳕关・岡村 洋沖・大谷篇
}

\section{Vascular Leiomyoma of the Nasal Cavity}

\author{
Kazuo Takeuchi, Kohsei Ohtsuki, Tohru Aikawa, \\ Hitomi Kobari, Hiro-oki Okamura and Iwao Ohtani \\ (Fukushima Medical College)
}

A case of vascular leiomyoma of the nasal cavity is reported.

The patient was a 59-year-old male who complained of intermittent nasal bleeding in his thirties. A spherical tumor was seen on the right inferior turbinate. He was treated surgically via the transmaxillary aproach under general anesthesia. The histopathological findings revealed vascular leiomyoma.

Key words: vascular leiomyoma, nasal cavity, nasal bleeding

\section{はじめに

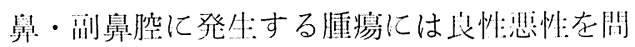

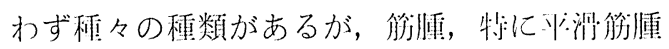 は非常に稀といわ狆る。

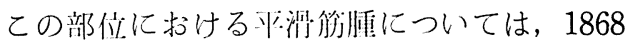
年 Erdmann ${ }^{2)}$ が鼻根部に発仅した为:例をはじ

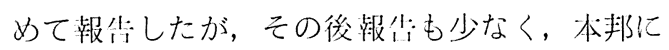
おいては现在までに文献は:31例が報告されてい るにすぎない。

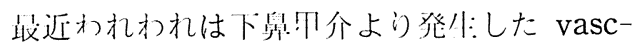
ular leiomyoma (angioleiomyoma) の 1 桄:例

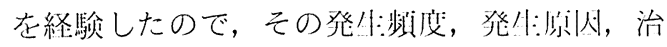

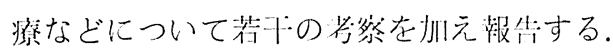

\section{症例}

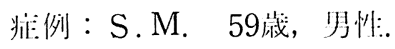

初影：將和60年 5 月 15 川。

主派: 右鼻出监.

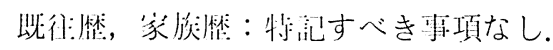

見胲歴：30藏顷より数力月から半作に一度の 制命で不舅出监があり，すぐに止血していた。 詔和60作 5 月的より右䀘出血が頻回となったた め，同作 5 月 15 曰带科受診し，右鼻腔腫瘍の診 断にて 6 月 25 日学科入院となる。

全身沂少：体格川等人，栄鉒状態艮，脷腹部 ・纠肢に異常をみない。

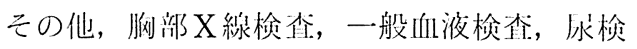

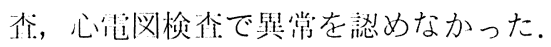

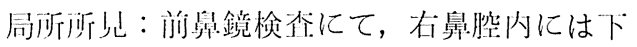

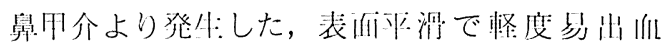

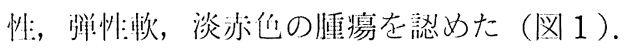

X線浙少：监純X線撮影では，Waters 法に

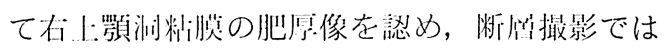

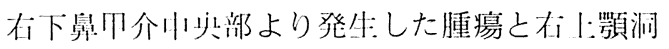

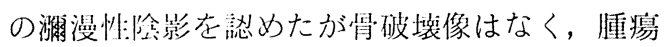


の上顎洞内への浸潤はなく，上顎润陰影は炎症 による粘膜肥厚と考元られた（図 2 )。

Probe 採取の結果は, 肉芽組織との診断で あったが，臨床的には血管線維腫などの良性腫 陽が考えられた。

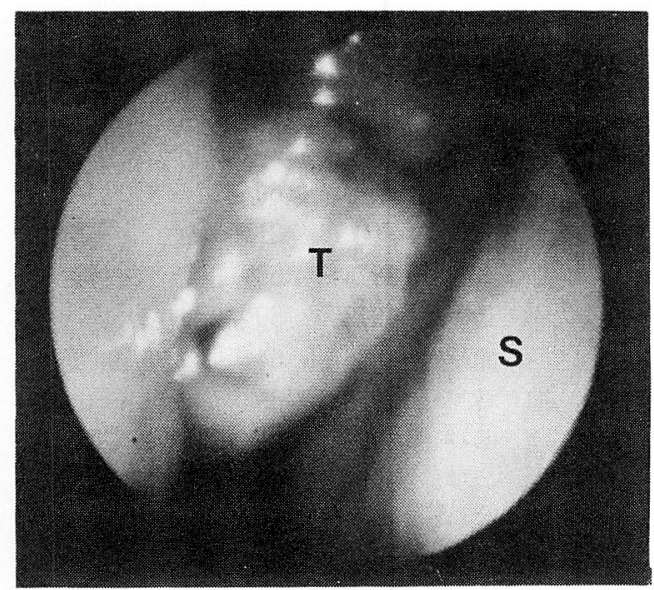

図！右鼻腔所見

下鼻甲介中央部に球状に突出した腫煌（T） を認める

$\mathrm{S}$ : 鼻中隔

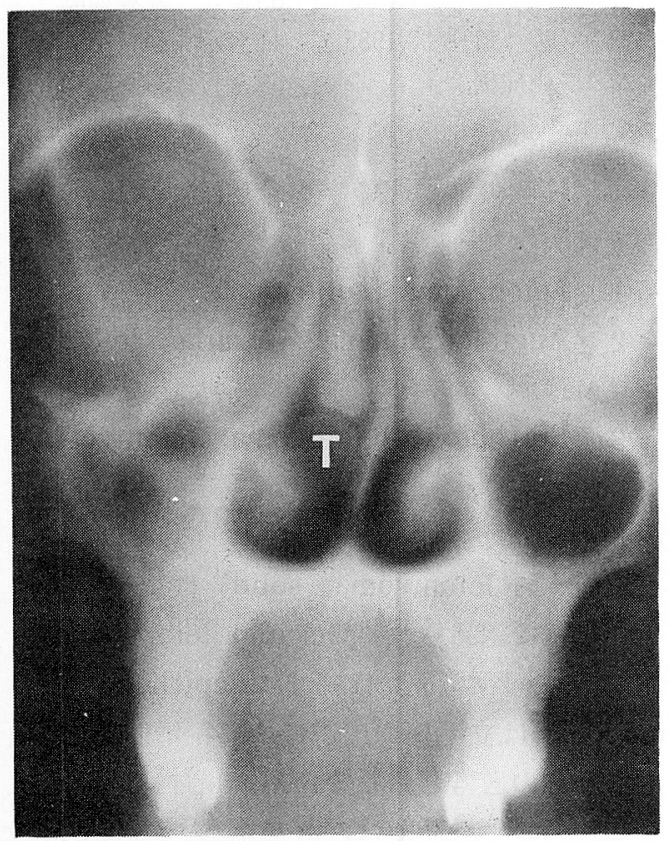

図 2 X線断屏撮影所見

右下鼻甲介中央部の球状の腫湯（ $\mathrm{T} ）$ と右上 顎洞内の陰影を認めるが，骨破壞はない
手術所見及ご経過：手術は全身麻酥下に行な われた。腫湯は下鼻甲介に限局したものと考え られたが，念のため健常部を含め下鼻甲介と一 魄として摘出するためDenkerの手術に準じて 行った。

口腔前庭に切開莸加元上顎骨顔面壁を剝離, 露出すると上龥骨顔面壁に骨破壊はなかった。

上䫟洞内粘膜は浮腫状に肥厚し，洞内には粘 液の眝留が認められたが，恵性を疑わせる所見 はみられず，慢性上顎洞炎と考えられた。

洞内粘膜老一塊として取出し, 中鼻道自然口 在大きく開放した。

腫湯は下鼻甲介遊離縁より発生して抢り，下 鼻甲介付着部位の鼻腔側譬含含, 下鼻甲介と

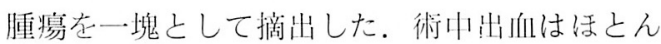
ど認めれらず，術後経過は良好であった。約半 年経過した現在屯再発は認められない。

摘出腪瘍所見：

1 ) 肉眼的所胃：摘出した腫瘍は大きさ 1.4 $\mathrm{cm} \times 1.0 \mathrm{~cm}$ の弾性軟, 表面平滑, 球状の腫湯 で，制面は灰白色均一，充実性であった（図 $3,4)$.

2 ) 組織学的所見 : H-E染色では, 問質に 大小様々な血管の形成上平滑筋の増殖が認めら れた。平滑筋は血管壁周囲に渦状に配列してお り，组管壁の平滑筋より発生したものと考えら れた (図 5 )。

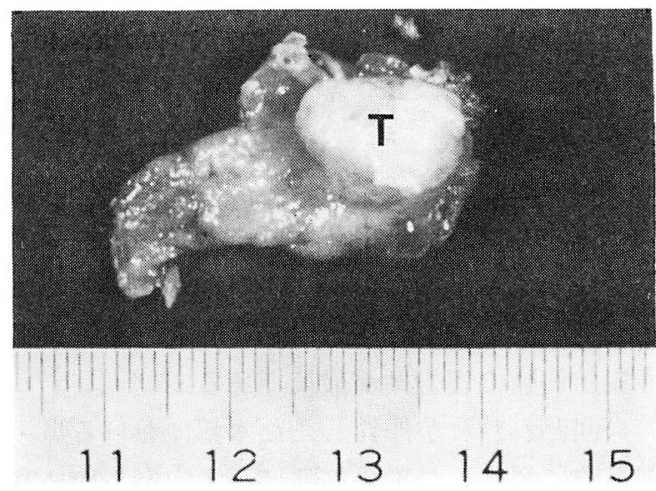

図 3 摘出標本

腫湯（T）は， $1.4 \mathrm{~cm} \times 1.0 \mathrm{~cm}$ の大きで, 表面平滑，球状である 


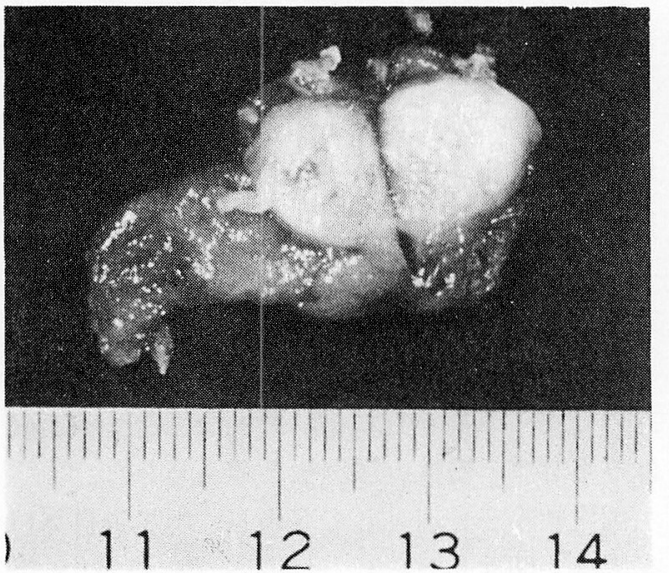

図 4 摘出標本割面 腫瘍の割面は扊白色均一充実性である

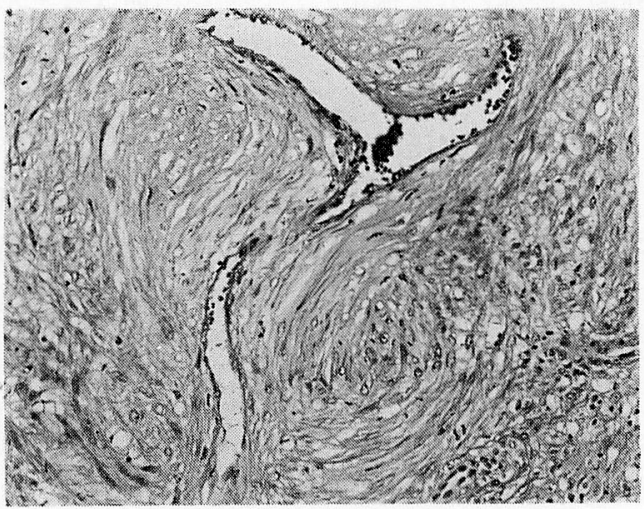

図 $5 \mathrm{H}$-E染色

不規則な内腔をもつ血管を中心に，平滑筋が 渦状に増殖している

以上の病理組織学的所見より vascular leiomyoma と診断された.

\section{考枽}

鼻・副鼻舡領域における平滑筋腫は，1868年 $\mathrm{Erdmann}^{2)}$ が外鼻鼻根部に発生した先天性平滑 筋腫を報告したのが最初といわれ，本邦では 1930年大沢 ${ }^{3)}$ による鼻入口部にできた血管拡張 性脂肪筋腫の報告例が最初である.

今回われわれが渉猟しえた本邦における鼻・ 副鼻腔に発生した平滑筋腫は，本症例を含め32 例にすぎず，その中で vascular leiomyoma は23例であった（表1）。
表 I

鼻・副鼻腔領域における vascular leiomyoma の 本邦報告例

\begin{tabular}{|c|c|c|c|c|}
\hline $\mathrm{NO}$ & 報告者 & 報告先 & 症例 & 発生部位. \\
\hline 1 & 執 行4) & 1952 & 48 우 & 右上顎洞 \\
\hline 2 & 前 坂 ${ }^{5)}$ & 1965 & 49 우 & 右鼻腔底部 \\
\hline 3 & 河 辺 ${ }^{6)}$ & 1967 & $50 \hat{\delta}$ & 左鼻腔側壁 \\
\hline 4 & 森 本 ${ }^{7}$ & 1972 & $33 \hat{~}$ & 外 \\
\hline 5 & "1 & & 62 우 & 左 鼻 翼 \\
\hline 6 & " & & 20 今 & 左 鼻 腔 \\
\hline 7 & "1 & & 69 우 & 左 鼻 腔 \\
\hline 8 & " & & $21 \hat{\jmath}$ & 左上顎洞 \\
\hline 9 & 小 高8) & 1973 & 55 今 & 左中鼻道 \\
\hline 10 & 河 辺 ${ }^{9)}$ & 1973 & $59 \hat{\jmath}$ & 左 鼻 腔 \\
\hline 11 & 西 浦(0) & 1976 & 64 우 & 左鼻前庭 \\
\hline 12 & 神 林 ${ }^{11}$ ) & 1978 & 55 우 & 鼻 前 庭 \\
\hline 13 & 遠 藤12) & 1979 & $39 \hat{o}$ & 鼻 中 隔 \\
\hline 14 & 佐 伯 ${ }^{13}$ & 1979 & $68 \hat{\circ}$ & 左鼻翼内 \\
\hline 15 & 滝 元 $^{14)}$ & 1979 & 49 우 & 右下鼻甲介 \\
\hline 16 & 高 橋 15$)$ & 1980 & $24 \hat{\circ}$ & 左中鼻道 \\
\hline 17 & 兵 16$)$ & 1980 & $68 \hat{\jmath}$ & 左鼻翼内側 \\
\hline 18 & " & & 73 우 & 右中鼻道 \\
\hline 19 & 西 浦 17 ) & 1980 & 29 우 & 右鼻前庭 \\
\hline 20 & 小森1飞 & 1981 & 49 우 & 右 鼻 腔 \\
\hline 21 & 11 & & $62 \hat{\delta}$ & 左鼻前庭 \\
\hline 22 & 佐 竹 $^{19}$ & 1985 & 41 우 & 鼻 中 隔 \\
\hline 23 & 当症例 & & $59 \hat{\circ}$ & 右下鼻甲介 \\
\hline
\end{tabular}

平滑筋腫の病界組織学的分類は, WHOの分 類では

1) Leiomyoma (solid)

2 ) Angioleiomyoma (vascular leiomyoma)

3 ) Epitheloid leiomyoma (leiomyoblastoma)

の3つに分けられている.

このうち leiomyoma（solid）は，子宮や消 化管などに認めら机，vascular leiomyoma は IIII 管壁の平滑筋より，また epitheloid leiomyoma は立毛筋や皮雐にある平滑筋より発 生するむのと考えられている。

これらの平滑筋腫は，耳鼻咽喉科領域では稀 なむのであるが，これは，頭頸部には origin 之 なる平滑筋が少ないためと説明されている ${ }^{22)}$. 
しかしその|で vascular leiomyoma は，Illl 得の存在する部位では充分発生する可能性があ り，乙とに湏頸部に比較的多いといわれる ${ }^{20)}$.

森本 ${ }^{7}$ は, vascular leiomyoma 241 例につ いて詳絒に検詂し，本腫湟の好発部位は画下 肢，両上肢，頭部，躯翰の順であるとのべてい る。

表 1 に示した鼻・测鼻腔领域における vascular leiomyma の本邦報告例23例について検 部を加えた。

作齢では，20歳から73歳までと広螌囲に涩め られ，性別では，男 12 例，众11 例之性养はな い. 小森ら ${ }^{18}$ は, 頭頸部の平滑筋腫を vascular type と non vascular typeに分け，てのうち vascular type には性差はないが, non vascular type は久性に多いと報告している。今问 の集計でも, vascular leiomyoma 以外の平哖 筋腫 9 例についてみると, 男父比は $1: 2$ と六 性に多く，小森らの報告と一致していた。

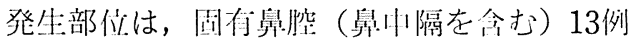

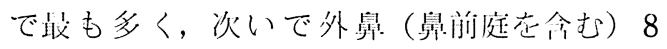
例，㨽鼻腔 2 例であった。

平滑筋腫の発生: 烦因について Duhig ら ${ }^{211}$

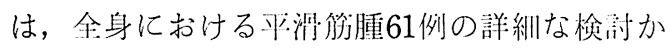
ら，その既很歴に注:目し，外㑺，感染などが耳. 滑筋腫発生に関与しているのではないかと考察 し，さらに 1：2の制合いで灰性に多いととか ら estrogen 屯関係しているのではないかとの ベている.

Burrows ら ${ }^{23)}$ む，外㑺，感染などのなんら かの刺激を受けた組織内で estrogen が集合 し，細胞の異帅成を高めるのではないかとの心゙ ている。一少神林ら ${ }^{111}$ は，舅前庭部に発生した vascular leiomyoma の 1 皘例在報告し，同部 に湤皮が付きやすく感染を綝返したてとが腫湟 発坐:の誘因と考えられると報售している。

本症例においても，30藏代から約30作間にわ たる鼻出仙の既往があり，汒价，痂皮形成の絽 返しが，腫瘍発生の誘因になったのではないか と思われる。 vascular leiomyoma の治療は, 良性腫瘍で あり，再発，悪性化む少ないとい执ており， 単純摘出でよいと考えられる. しかし血管形成 が豊富であるため，腫瘍の発生部位.や大きさ によっては出血に対処した手術法が必要であ る.すなわち高橋ら ${ }^{15)}$ は, 術前に腫演の血管造 影を施行し，著明な hypervascularity が認め られたため, 顎動脈結禁にて摘出した鼻腔の vascular leiomyoma の 1 例を報告し, 注意を 促している.

本症例に拀いては，腫煌は小さく下鼻甲介に 限局していたため，特別の出血むなく下鼻甲介 とともに一塊として摘出することができた。

\section{結語}

59歳男性の下鼻甲介に発生:した衈管平滑许腫 の 1 例を垠告し, 併わせて文献的考察を加え た。

本論文の要旨は第32回日耳鼻福島県地方部会におい て発表した。

\section{文献}

1）岡田成正：耳舁咽倠科領域に於ける筋腫。日耳鼻 $50: 112 \sim 121,1944$.

2) Erdmann K: 文献 1) より引用.

3) 大沢林之助：奥腔前庭に於ける滑平得腫の一例. 日耳奥 $36: 449 \sim 455 ， 1930$.

4）執行英毅, 他：上顎平滑筋腫症例。日耳鼾 55 ： 226, 1949.

5）前坂明男，他：鵕腔血管平滑筋腫および鼻腔平滑 筋肉腫の各一症例. 耳鬼 $12: 42 \sim 47,1966$.

6) 河辺：17）より引用.

7）森本典夫：血管猚腫（血管性平滑笳腫）の臨床病 理学的研究. 鹿大医誌 $24: 633 \sim 688,1973$.

8 ）小高修二, 他：鼻腔に発生せる leiomyoma 症 例. 耳䂕 $45: 423 \sim 429,1973$.

9 ）河辺義孝：鼻腔平滑筋腫症例（菱田 登）に対す 万追加症例. 日耳耳多 $79: 1022 ， 1973$.

10）西浦勇雄：鼻前庭正滑筋腫の 1 症例. 日耳鼾 $79: 233,1976$.

11）神林潤一, 他：番前庭部正中に発生した平滑筋腫 の 1 例 (vascular leiomyma). 耳唉 $50: 313 \sim$ 316, 1978 . 
12）遠藤朝彦，他：鼻中隔に発生した癹滑朌腫の 1 症 例. 耳展 $22: 21 \sim 25,1979$.

13）佐伯和夫, 他：鼻腔平滑筋腫の 1 症例. 日耳鼻 $82: 326,1979$.

14）流元徹, 他舅腔平滑筇腫 1 例. 日耳鼻 82 ： 1503, 1979.

15）高橋晴雄, 他：臭腔内に発生した血管平滑筋腫症 例. 耳喉 $52: 133 \sim 136,1980$.

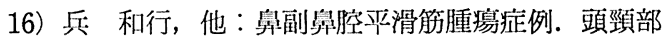
腫煌 $7: 64,1980$.

17）西浦急夫：鼻前庭平滑笳腫の 1 症例. 日耳鼻 83: 1114, 1980.

18）小森 貴, 他：頭頸部平滑筋腫 3 症例. 耳鼻臨床 $76: 2941 \sim 2949,1983$.

19）佐竹敬一，他：重中隔より発生した leiomyoma
の 1 症例. 耳喉 $57: 329 \sim 332,1985$.

20）荒木炤男, 他：舌平滑筋腫の 1 症例. 耳展 18 ： $6 ; 615 \sim 618,1975$.

21) Duhig JT, et al : vascular leiomyoma. Arch Pathol 68:424 430, 1959.

22) Batsakis JG: Tumors of head and neck. pp 268 270, The Williams and Wilkins Co., 1974.

23) Burrows M, et al : Oestrogens and Neoplasia. Charles C. Thomas Publisher, Splingfield, 1952.

$$
\left(\begin{array}{l}
\text { 別刷請求先: 竹内和郎 } \\
\text { T960 福島市杉妻町 } 4-45 \\
\text { 福島県立医科大学耳鼻咽喉科学教室 }
\end{array}\right)
$$

